\title{
SARS-CoV-2-fertőzés és COVID-19 Gaucher-kóros betegekben: a védőoltás javallata
}

\author{
Maródi László dr. \\ Semmelweis Egyetem, Általános Orvostudományi Kar, Bőr-, Nemikórtani és Dermatoonkológiai Klinika, \\ Primer Immundeficiencia Klinikai Egység és Laboratórium, Budapest
}

\begin{abstract}
Az új típusú koronavírus (SARS-CoV-2) okozta pandémia kezdetén a szakmai közvélemény általános vélekedése a Gaucher-kóros betegek fokozott érzékenységét vetítette elö, magas morbiditási és mortalitási mutatókkal. Meglepő módon azonban az eddigi, nagyszámú betegen, az Egyesült Államokban, Európában és Izraelben végzett klinikai tanulmányok azt mutatják, hogy ezen súlyos anyagcsere-betegségben sem a fertőzésnek kitett betegek morbiditási adatait, sem a ritkán kialakult fertőzések súlyosságát tekintve nem áll fenn csökkent immunvédekezés a SARS-CoV2 -vel szemben. Ezen immunológiai és infektológiai paradoxon lehetséges magyarázata, hogy a betegek makrofágjaiban és más sejtjeiben felhalmozódó glükocerebrozid gyulladásos állapotot tart fenn, amely hátrányos a kórokozó vírus intracelluláris túlélése szempontjából. A közleményben összefoglaljuk a témakörben eddig megjelent tanulmányok adatait, az általános prevencióval és a vakcinációval kapcsolatos ajánlásokat, és kitérünk az l-es típusú interferonok (IFN $\alpha$ és IFN $\omega)$ közelmúltban megismert szerepére a SARS-CoV-2-vel szembeni immunitásban.
\end{abstract}

Orv Hetil. 2021; 162(24): 938-942.

Kulcsszavak: SARS-CoV-2, COVID-19, ACE, APECED

\section{SARS-CoV-2 infection and COVID-19 in Gaucher disease: indications for vaccination}

At the start of the pandemic caused by the novel coronavirus (SARS-CoV-2), the Gaucher disease community anticipated that infection with this emerging viral pathogen would be associated with high morbidity and mortality in individuals with this chronic metabolic disorder. Surprisingly, however, preliminary studies suggest that Gaucher disease does not confer a higher risk of severe, life-threatening effects of SARS-CoV-2 infection, and no severe cases have been reported in large cohorts of patients from the United States, Europe and Israel. It is thought that the accumulation of glucocerebroside in the cells of Gaucher patients may promote immune tolerance rather than inflammation on exposure to SARS-CoV-2. We review here the current concepts of Gaucher disease and SARS-CoV-2 infection, focusing particularly on general prevention and vaccination. We also discuss the susceptibility to COVID-19 of patients with inborn errors of type 1 interferon (IFN $\alpha$ and IFN $\omega$ ) immunity.

Keywords: SARS-CoV-2, COVID-19, ACE, APECED

Maródi L. [SARS-CoV-2 infection and COVID-19 in Gaucher disease: indications for vaccination]. Orv Hetil. 2021; 162(24): 938-942.

(Beérkezett: 2021. április 4.; elfogadva: 2021. április 21.)

\section{Rövidítések}

$\mathrm{ACE}=$ (angiotensin-converting enzyme) angiotenzinkonvertáló enzim; APECED = autoimmun polyendocrinopathia, candidiasis, ectodermalis dysplasia; COVID-19 = (coronavirus disease 2019) koronavírus-betegség 2019; FDA = (U.S. Food and Drug Administration) az Amerikai Egyesült Államok Élel- miszer-biztonsági és Gyógyszerészeti Hivatala; IFN $\alpha=$ interferon-alfa; IFN $\omega=$ interferon-ómega; $\mathrm{mRNS}=$ (messenger ribonucleic acid [RNA]) hírvivő ribonukleinsav; SARS-CoV-2 = (severe acute respiratory syndrome coronavirus 2 ) súlyos akut légúti szindrómát okozó koronavírus-2 
A COVID-19 (coronavirus disease 2019; koronavírusbetegség 2019 ) - amelynek kórokozója a SARS-CoV-2 (severe acute respiratory syndrome coronavirus 2; súlyos akut légúti szindrómát okozó koronavírus-2) - 2019 óta ismert, először Kínában (Hupei tartomány, Wuhan város) felbukkant, majd hamarosan az egész világon elterjedt, jelentős mortalitású fertőző betegség [1]. A megbetegítőképesség szempontjából fontos szerepet játszanak a tüskefehérjék, amelyek a hámsejtek angiotenzinkonvertálóenzim (ACE)-2-receptorához kötődnek, majd a vírus-receptor-komplex bejut a sejtekbe $[2,3]$.

A megbetegedettek száma 2021. januárra már elérte a 96 milliót, a halálesetek száma pedig a 2 milliót [4]. A COVID-19 egy év alatt, csak az Egyesült Államokban, 24 millió megbetegedést okozott, és 400 ezer halálos áldozatot követelt [4]. A megbetegedettek és a halálos áldozatok száma Magyarországon is magas. A fertőzés terjedésének megfékezésére a világ nagy gyógyszergyártó vállalatai drámai gyorsasággal többféle, új vakcinát fejlesztettek ki. A vakcinakutatáshoz és -előállításhoz külföldön dolgozó magyar kutatók is nagyban hozzájárultak $[5,6]$. A lakosság megfelelő arányban történő immunizálása és a társadalmi, gazdasági élet világjárvány előtti állapotának helyreállítása a járvány sújtotta területeken hónapokat, sőt éveket vesz igénybe, és nehéz, számos országban megoldhatatlan feladat elé állítja az egészségügyi ellátórendszert.

A ritka betegségben szenvedők a jelenlegi kritikus járványhelyzetben megkülönböztetett szakmai odafigyelést és ellátást igényelnek. A közleményben rövid áttekintést adunk a veleszületetten fogékony és a Gaucher-kórban szenvedő betegek SARS-CoV-2-fertőzésével kapcsolatos ismeretekről, külön hangsúllyal az általános megelőzésre, a specifikus fogékonyságra és a vakcinációra.

\section{A járvány jellemzői}

A világjárvány kezdeti időszakában általánosan jellemző volt, hogy a COVID-19 elsősorban az idősebb korosztály képviselői (65 év felettiek) és a krónikus betegségekben szenvedők körében jár magas morbiditással és mortalitással. A későbbiek során azonban, elsősorban az új mutáns SARS-CoV-2 vírusok megjelenésével párhuzamosan, a betegség áldozatai között egyre nagyobb számban vannak a fiatalabb korosztályokhoz tartozók és az egészségesek. Sok más vírushoz (például influenzavírusok) hasonlóan a koronavírusok is variábilisak, változhat a génállományuk és a molekuláris szerkezetük, és a korábbi variánssal szemben kialakult specifikus immunitás - akár természetes fertőzés útján, akár védőoltás eredményeképpen jött létre - nem lesz kellően hatékony az immunvédekezéshez. Az egyik ilyen, B.1.1.7 megjelölésú, agresszív variánst először Angliában izolálták [7]. Hamarosan kiderült, hogy az új mutáns vírus az egyik legfenyegetőbb veszély a pandémiában, mert súlyosabb megbetegedést okoz, és fertőzőképesebb, mint a világjárvány kezdetén megjelent kórokozó. A 2020 őszén izolált va- riáns hamarosan világszerte, így Magyarországon is elterjedt, és az USA-ban fél éven belül a COVID-19-esetek 26\%-át okozta [4]. Ez a járvány megfékezése és megállítása szempontjából kedvezőtlen körülmény indokolja a megelőző óvintézkedések (maszk viselése, kézmosás, távolságtartás) folyamatos betartását ott is, ahol a lakosság jelentős részét már védőoltásban részesítették.

\section{Veleszületett fogékonyság koronavírus- fertőzésre}

A fertőzésekkel szembeni fogékonyságot nemcsak a vírusok szerkezetében bekövetkező változások befolyásolják, hanem az immunvédekezés veleszületett vagy szerzett zavarai is. A veleszületetten immunhiányos betegségek száma közel 500, és fő klinikai jellemzőjük a fertőzésekkel szembeni fogékonyság [8-10]. Az immunológiai és a genetikai kutatások arra utalnak, hogy az életkortól és az alapbetegségtől függetlenül fokozott mértékben kell számolni a COVID-19 kialakulásával és annak súlyosabb kimenetelével azoknál, akikben az I. típusú interferonok $(\mathrm{IFN} \alpha)$ múködését hátrányosan befolyásoló génhibák állnak fenn, vagy ilyen típusú interferonokkal szembeni autoantitesteket termel a szervezetük [11, 12]. Nagyszámú beteganyag tanulmányozása arra utal, hogy súlyos COVID-19-fertőzés esetében a betegek 10\%-ának vérében mutatható ki I. típusú interferonokkal (IFN $\alpha$ és IFN $\omega$ ) szembeni ellenanyag, míg a tünetmentes SARSCoV-2-fertőzöttek és az egészséges kontrollok széruma kevesebb mint 1\%-ban tartalmaz ilyen ellenanyagokat. Ezen megfigyelés különösen jelentős annak ismeretében, hogy a veleszületett immunhiányos betegségek egy típusában (az autoimmun polyendocrinopathia szindróma 1. típusa, vagy más néven autoimmun polyendocrinopathia, candidiasis, ectodermalis dysplasia [APECED-] szindróma) a betegek vérében már korai csecsemókortól kimutathatók I. típusú interferonokkal szembeni ellenanyagok [13]. Az ilyen betegek korai védőoltása, a súlyos COVID-19 megelőzésére, az eddigi megfigyelések tükrében különösen indokolt, de a fertőzésekkel szembeni általános fogékonyságra tekintettel minden veleszületett immunhiányos beteg elsőbbségi megfontolást igényel a vakcináció szempontjából.

\section{Fogékonyság Gaucher-kóros betegekben}

A Gaucher-kór az egyik leggyakoribb anyagcsere-betegség és a leggyakoribb lizoszomális tárolási betegség [14]. A betegek ellátása a legtöbb fejlett országban jól szervezett, és a rendelkezésre álló gyógyszerekkel igen eredményes [15]. A betegekkel foglalkozó orvosok, kutatók, alapítványok és betegközösségek számára is a legfontosabb kérdés napjainkban, hogy a betegség jelent-e fokozott kockázatot a SARS-CoV-2-fertőzéssel szemben, és hajlamosít-e COVID-19 kialakulására. A kérdés megválaszolása nem egyszerü, hiszen az alapbetegség komplex, 
és a patomechanizmus a fertőzésekkel szembeni immunitást is több ponton érinti $[14,16,17]$. Fontos továbbá különválasztani a kezelt és a kezeletlen betegeket, mivel a kezelés - mind az enzimpótló, mind a szubsztrátgátló terápia - képes helyreállítani a kóros anyagcsere-folyamatokat és az immunitást is. Figyelembe kell vennünk továbbá, hogy a Gaucher-kór nem egységes betegség, amely minden érintett betegben egyforma tünetekkel és panaszokkal jár, és vannak olyanok is, akikben a betegség akár egész életen át felismerés nélkül marad.

A Gaucher-kór mint lizoszomális tárolási betegség biokémiai alapjainak ismeretében több feltételezés fogalmazható meg amellett, hogy a koronavírus-fertőzésekkel szembeni fogékonyság nagyobb, mint egészséges személyekben. Az eddigi megfigyelések azonban ezt a feltételezést - paradox módon - nem támasztják alá. A New York-i Mount Sinai Kórház és a Yale Egyetem orvosainak megfigyelése szerint a New York város epicentrumában élő, vírusfertőzésnek kitett, 181 beteg (150 felnőtt és 31 gyermek) között csak kis számban fordultak elő a vírusfertőzés tünetei [18]. A megfigyelt betegek 78\%-a valamilyen kezelésben részesült az alapbetegség miatt. A 94 tesztelt beteg közül csak 18 esetben mutattak ki vírusátvitelt igazoltan SARS-CoV-2-fertőzöttekkel való találkozást követően. A megfertőződött betegek egyikében sem fordult elő COVID-19 vagy haláleset. Ezek a megfigyelések bizakodásra adnak okot, és nem utalnak arra, hogy a Gaucher-kóros betegek fokozottan érzékenyek lennének SARS-CoV-2-fertőzésre. Fontos azonban kiemelni, hogy a vizsgálatokat a világjárvány kezdeti szakaszában végezték, amikor a diagnosztikai tesztek még kevéssé voltak pontosak, mint a későbbi időszakban. A vizsgált beteganyag homogén volt, ami a megállapítások általános érvényességét korlátozza; mindössze 3 betegben állt fenn 3-as típusú Gaucher-kór, és csak 11 esetben történt a vizsgálatot megelőzően lépeltávolítás. Mindezek természetesen nem csökkentik azon megállapítások jelentőségét, hogy egyetlen betegben sem volt súlyos a fertőzés, és kórházi felvételre nem volt szükség. Egy Spanyolországban végzett európai tanulmányban beszámoltak ugyan egy halálos kimenetelú fertőzésről, a beteg azonban 79 éves volt, és cukorbetegségben is szenvedett, tehát két olyan körülmény is fennállt, amelyekról tudott, hogy kockázati tényezőt jelentenek a COVID-19 vonatkozásában.

\section{Védőoltás}

A Gaucher-kóros betegek klinikai ellátásában részt vevő amerikai orvosok egy mértékadó csoportja 2021. januárban szakmai véleményt fogalmazott meg és juttatott el az USA-ban kezelt betegekhez a védőoltásokkal kapcsolatban. Az álláspontot a betegek és betegcsoportok által leggyakrabban megfogalmazott, alábbi kérdésekre állították össze, így az általános érvényưnek tekinthető (E. Sidransky, személyes közlés).

\section{Szükséges-e a Gaucher-kóros betegek védöoltása?}

A koronavírus-járvány az USA-ban - és globálisan is felszálló szakaszában van. A COVID-19 súlyos, bizonytalan kimenetelú, nemritkán halálos betegség, és a SARSCoV-2-fertőzés kockázata összehasonlíthatatlanul nagyobb, mint az egészségügyi hatóságok által ellenőrzött és alkalmazásra jóváhagyott védőoltások ismert mellékhatásai. A Food and Drug Administration (FDA) álláspontjára is hivatkozással a 16 évnél idösebb, Gaucherkóros betegek számára COVID-19-védöoltás - az aktuális járványhelyzet és a társuló betegségek figyelembevételével indokolt. Az illetékes egészségügyi hatóságok által szigorúan ellenőrzött és engedélyezett vakcinák biztonságosak és hatékonyak. Nincsenek adatok arra vonatkozóan, hogy a vakcinák - általában néhány napig tartó - mellékhatásai (enyhe helyi oltási reakció, lokális fájdalom vagy bőrpír, hőemelkedés, mérsékelt fokú láz) a Gaucher-kóros betegekben gyakoribbak vagy súlyosabbak lennének, mint egészséges személyekben. Az eddigi megfigyelések alapján a súlyos allergiás oltási szövődmények extrém ritkák. Akik gyógyszerre vagy ételre allergiások, azoknál a védőoltás után 30 percig orvosi megfigyelés szükséges. Az enzimkezelés napján a vakcina adása nem javasolt. Akik korábban átestek COVID-19 betegségen, azok a betegség lezajlása után 3 hónappal kaphatnak védőoltást.

\section{Okozhat-e a vakcina COVID-19 betegséget?}

Az USA-ban engedélyezett oltóanyagok ún. mRNS-vakcinák, amelyek gyengített élő vagy elölt vírust nem tartalmaznak; az oltás tehát COVID-19 betegséget nem okoz. Az mRNS-sel olyan genetikai üzenetet juttatnak be az oltott szervezetébe, amelynek alapján a szervezet szintetizálni képes a vírus felszíni tüskefehérjéjét. Ezt követően az idegenként felismert fehérjével szemben a szervezet immunrendszere olyan ellenanyagokat termel, amelyek védő hatásúak a később esetlegesen bekövetkező fertőző, vad vírussal szemben.

\section{Gyermekeknek adbató-e COVID-19-pakcina?}

A jelenleg forgalomban lévő vakcinák 16 évnél idősebbeknek adhatók. Kisebb gyermekek esetében, a jelenleg folyamatban lévő klinikai tanulmányok eredményei alapján, várhatóan hónapokon belül engedélyezik a védőoltásokat.

\section{Élveznek-e a Gaucher-kórosok soronkivüliséget a COVID-19-vakcinával kapcsolatban?}

A védőoltások bevezetésekor az idős (általában 65 évnél idősebb) és krónikus alapbetegségben szenvedők kaptak elsőként védőoltást. Ez az életkor azonban az oltások kiterjesztésével párhuzamosan csökken. Fontos hangsúlyozni, hogy a Gaucher-kór, bár súlyos alapbetegségnek 
tekintendő, egyéb alapbetegség hiányában nem hajlamosít súlyosabb lefolyású SARS-CoV-2-fertőzésre. Ha azonban a Gaucher-kór korábban súlyos komplikációt okozott, a beteg splenectomiában részesült, vagy az anyagcsere-betegség mellett krónikus szívbeteg, tüdőbeteg, vesebeteg, elhízott, diabeteses, véralvadási vagy immunológiai betegsége is van, a védőoltás indokolt, és a soronkívüliséget a beteg a kezelőorvosával egyeztesse. Végezetül fontos tanács, hogy a járványfolyamat visszaszorításáig az általános óvó rendszabályok betartása védőoltás után is kötelező.

\section{A kutatások várható iránya}

A világjárvány folytatódása miatt várható, hogy a közeljövőben folyamatosan jelennek meg újabb megfigyelések, amelyekben prospektív, megtervezett vizsgálatok eredményeiról és egyre nagyobb számú beteganyagon végzett tanulmányokról olvashatunk. Több ilyen vizsgálathoz már elkezdődött az anyaggyújtés nagyobb, nemzetközileg is jól ismert kezelöközpontokban. Ezen vizsgálatok értékét várhatóan növeli, hogy idővel a diagnosztikai tesztek megbízhatóbbak, a diagnosztikai kritériumok pontosabbak lesznek. Újabb adatok várhatók annak megítélésére, hogy a Gaucher-kóros betegek makrofág sejtjeiben felhalmozódó anyagcseretermékek (glükocerebrozidok) csökkentik vagy éppen fokozzák a vírusok elölésének és eltávolításának képességét ezekben a sejtekben, következésképpen a szervezet egészében. In vitro vizsgálatok arra utalnak, hogy a glükocerebrozidok tárolása miatt a proinflammatiós citokinek és a tumornekrózis-faktor termelése fokozott, a szérumferritin- és -D-dimer-szint emelkedett, és a krónikus gyulladás a betegség kórélettanának része [19]. Mivel a vírusfertőzés folyamatában a sejtek lizoszómájában különösen fontos folyamatok zajlanak le, izgalmas eredmények várhatók arra vonatkozóan, hogy a Gaucher-kórban a lizoszómákban felhalmozott zsíranyagcsere-termékek által megváltoztatott lizoszomális mikrokörnyezet kedvező vagy kedvezőtlen a SARS-CoV-2 sejten belüli túlélése szempontjából. Mindezen megfigyelések a SARS-CoV-2-fertőzött Gaucher-kóros betegek kezelésében is új megoldásokat és eljárásokat eredményezhetnek, és az eddigi terápiás eljárások ma még nem látható továbbfejlesztéséhez vezethetnek [20].

A közlemény írásakor már megjelent, további két közleményre $[21,22]$ is hivatkozással összefoglalóan az állapítható meg, hogy bekövetkezett SARS-CoV-2-fertőzés vagy kialakult COVID-19 esetén a Gaucher-kór önmagában nem jelent fokozott kockázatot. Az epidemiológiai megfigyelések arra utalnak, hogy a súlyos SARS-CoV2-fertőzés és a COVID-19 férfiakban gyakoribb. Kockázati tényezőt jelent továbbá az 1-es és a 2-es típusú cukorbetegség, a krónikus vesebetegség, az immunhiány-állapotok (l. feljebb), a krónikus szív- és tüdőbetegség. Mindezek a kockázati tényezők Gaucher-kórban az alapbetegség miatt fokozottan érvényesülnek, különösen azokban, akik kezelésben még nem részesültek, vagy korábban lépeltávolításon estek át. Az ilyen betegekben a makrofágok múködésének zavara, a krónikus gyulladásos állapot, amelyet a zsíranyagcsere-termékek felhalmozódása tart fenn, általánosságban fertőzésre hajlamosító körülmények lehetnek, és indokolják a SARS-CoV-2-fertőzés megelőzésére előírtak fokozott betartását. A védőoltásokkal kapcsolatban jelenleg rendelkezésre álló ismeretek alapján célszerü a 16 éves vagy idősebb Gaucher-kóros betegek immunizációja mRNS típusú védőoltással.

Anyagi támogatás: A közlemény megírása, illetve a kapcsolódó kutatómunka anyagi támogatásban nem részesült.

A cikk végleges változatát a szerző elolvasta és jóváhagyta.

Érdekeltségek: A szerzőnek nincs érdekeltsége.

\section{Irodalom}

[1] Centers for Disease Prevention and Control. Severe outcomes among patients with coronavirus disease 2019 (COVID-19) United States, February 12-March 16, 2020. Morb Mortal Wkly Rep. 2020; 69: 343-346.

[2] Li G, Fan Y, Lai Y, et al. Coronavirus infections and immune responses. J Med Virol. 2020; 92: 424-432.

[3] Gheblawi M, Wang K, Viveiros A, et al. Angiotensin-converting enzyme 2: SARS-CoV-2 receptor and regulator of the renin-angiotensin system. Celebrating the 20th anniversary of the discovery of ACE2. Circ Res. 2020; 126: 1456-1474.

[4] Centers for Disease Control and Prevention. Coronavirus disease 2019. Available from: https://www.cdc.gov [accessed: April 4, $2021]$.

[5] Laczkó D, Hogan MJ, Toulmin SA, et al. A single immunization with nucleoside-modified mRNA vaccines elicits strong cellular and humoral immune responses against SARS-CoV-2 in mice. Immunity 2020; 53: 724-732.e7.

[6] Sahin U, Muik A, Derhovanessian E, et al. COVID-19 vaccine BNT162bl elicits human antibody and TH1 T cell responses. Nature 2020; 586: 594-599.

[7] Volz E, Mishra S, Chand M, et al. Assessing transmissibility of SARS-CoV-2 lineage B.1.1.7 in England. Nature 2021 Mar 25. Doi: 10.1038/s41586-021-03470-x. [Epub ahead of print]

[8] Bousfiha A, Jeddane L, Picard C, et al. Human inborn errors of immunity: 2019 update of the IUIS phenotypical classification. J Clin Immunol. 2020; 40: 66-81.

[9] Maródi L. Interdisciplinary immunodeficiency: a novel approach to understanding primary immunodeficiency disorders. [Interdiszciplináris immundeficientia: új szemlélet a primer immunhiány-betegségek értelmezésében.] Orv Hetil. 2018; 159: 895897. [Hungarian]

[10] Pac M, Casanova JL, Reisli I, et al. Advances in primary immunodeficiencies in Central-Eastern Europe. Front Immunol. 2021/Front Immunol.2021; doi: 10.3389/fimmu. Vol 12: 667727.

[11] Bastard P, Rosen LB, Zhang Q, et al. Autoantibodies against type I IFNs in patients with life-threatening COVID-19. Science 2020; 370: eabd4585. 
[12] Zhang Q, Bastard P, Liu Z, et al. Inborn errors of type I IFN immunity in patients with life-threatening COVID-19. Science 2020; 370: eabd4570.

[13] Tóth B, Wolff AS, Halász Z, et al. Novel sequence variation of AIRE and detection of interferon- $\omega$ antibodies in early infancy. Clin Endocrinol. 2010; 72: 641-647.

[14] Zimran A, Elstein D. Gaucher disease and related lysosomal storage diseases. In: Lichtman M, Beutler E, Kipps TJ. (eds.) Williams' hematology. McGraw-Hill, New York, NY, 2016. Chapter 72 .

[15] Erdős M, Hodanova K, Taskó S, et al. Genetic and clinical features of patients with Gaucher disease in Hungary. Blood Cells Mol Dis. 2007; 39: 119-123.

[16] Maródi L, Káposzta R, Tóth J, et al. Impaired microbicidal capacity of mononuclear phagocytes from patients with type I Gaucher disease: partial correction by enzyme replacement therapy. Blood 1995; 86: 4645-4649.

[17] Pandey MK, Burrow TA, Rani R, et al. Complement drives glucosylceramide accumulation and tissue inflammation in Gaucher disease. Nature 2017; 543: 108-112.

[18] Fierro L, Nesheiwat N, Naik H, et al. Gaucher disease and SARSCoV-2 infection: experience from 181 patients in New York. Mol Genet Metab. 2021; 132: 44-48.
[19] Ilan Y. $\beta$-Glycosphingolipids as mediators of both inflammation and immune tolerance: a manifestation of randomness in biological systems. Front Immunol. 2019; 10: 1143.

[20] Ginns EI, Ryan E, Sidransky E. Gaucher disease in the COVID-19 pandemic environment: the good, the bad and the unknown. Mol Genet Metab. 2021; 132: 213-214.

[21] Andrade-Campos M, Escuder-Azuara B, de Frutos LL, et al. Direct and indirect effects of the SARS-CoV-2 pandemic on Gaucher disease patients in Spain: time to reconsider homebased therapies? Blood Cells Mol Dis. 2020; 85: 102478.

[22] Zimran A, Szer J, Revel-Vilk S. Impact of Gaucher disease on COVID-19. Intern Med J. 2020; 50: 894-895.

(Maródi László dr., Budapest, Mária u. 41., 1085 e-mail: marodi.laszlo@med.semmelweis-univ.hu

Jelenlegi munkahely: St. Giles Laboratory of Human Genetics of Infectious Diseases, The Rockefeller University, New York, NY. e-mail: Lmarodi@rockefeller.edu)

\section{"Extrema semper de ante factis iudicant." ( $A$ végső tett határozza meg az előzők ítéletét.)}

A cikk a Creative Commons Attribution 4.0 International License (https://creativecommons.org/licenses/by/4.0/) feltételei szerint publikált Open Access közlemény, melynek szellemében a cikk bármilyen médiumban szabadon felhasználható, megosztható és újraközölhetö, feltéve, hogy az eredeti szerző és a közlés helye, illetve a CC License linkje és az esetlegesen végrehajtott módositások feltüntetésre kerülnek. (SID_1) 